\title{
Induction of Giant Endothelial Cells in Culture by K-252a, a Protein Kinase Inhibitor
}

\author{
Kazuhiro Ohmi ${ }^{1}$, Shigeru Yamashita ${ }^{1}$, Yoshiaki Hashimoto ${ }^{2}$ and Yoshiaki Nonomura ${ }^{1, *}$ \\ 'Department of Pharmacology and ${ }^{2}$ First Department of Internal Medicine, Faculty of Medicine, The University of Tokyo, Bunkyo-ku, Tokyo 113, Japan
}

Received May 21, $1993 \quad$ Accepted July 8, 1993

\begin{abstract}
K-252a, a protein kinase inhibitor with a wide spectrum of activity, inhibited the serumstimulated proliferation of cultured bovine carotid endothelial cells dose-dependently, and all the cells became remarkably large, with a diameter of more than $150 \mu \mathrm{m}$ at K-252a concentrations of $0.3-1 \mu \mathrm{g} / \mathrm{ml}$. This effect of the agent was reproducible under the conditions described in this article. When the endothelial cells became abnormally large by $\mathrm{K}-252 \mathrm{a}$, the surface area of the cell became wider, and the F-actin molecules increased in both number and length. Despite their abnormal size, K-252a-induced giant cells maintained at least three physiological functions characteristic to normal endothelial cells: 1) ability to take up acetylated low density lipoprotein, 2) ability to produce and secrete endothelin and 3) ability to respond via an increase of $\left[\mathrm{Ca}^{2}\right]_{i}$ to the stimulation by bradykinin. These observations suggest that $\mathrm{K}-252 \mathrm{a}$-induced giant cells are useful tools for examining the function of endothelial cells because it is very reproducible and can be produced by an easy treatment.
\end{abstract}

Keywords: Endothelial cell, K-252a, Protein kinase inhibitor

Vascular endothelial cells (ECs) are localized at the interface between the blood and vessel wall and play a crucial role in the regulation of numerous physiological and pathological processes through their production and secretion of physiologically active substances. Some of these functions are closely related to the cell structure; hemodynamic forces affect the size, shape and orientation of ECs $(1,2)$, while various compounds can cause changes in their structure and growth (3-5). However, almost all the mechanisms for these processes have remained for the most part unsolved.

Recently, K-252a was found to be a potent inhibitor of protein kinase with a wide spectrum of action in vitro against many enzymes: $\mathrm{Ca}^{2+}$-phospholipid dependent protein kinase, adenosine $3^{\prime}, 5^{\prime}$-cyclic monophosphate (cAMP) dependent protein kinase, guanosine $3^{\prime}, 5^{\prime}$-cyclic monophosphate (cGMP) dependent protein kinase (6), smooth muscle myosin light chain kinase (7), phosphorylase kinase (8), calmodulin dependent cyclic nucleotide phosphodiesterase (9), and calcium-calmodulin kinase II (10). In the vascular system, K-252a supressed the contraction of arterial smooth muscle (11) and inhibited the proliferation of cultured smooth muscle cells from bovine

\footnotetext{
* To whom correspondence should be addressed.
}

carotid artery (12). Very recently, it was reported that $\mathrm{K}$ 252a induced DNA replication in rat diploid fibroblasts without an intervening mitosis, producing tetraploid cells (13). Thus, K-252a has unique and useful characteristics not found in other protein kinase inhibitors, and analyses using K-252a should reveal important cell functions.

In this study, we investigated the effect of K-252a on ECs, especially its action on the growth and structure, using cultured bovine carotid ECs. Moreover, we also examined whether the ECs treated with $\mathrm{K}-252 \mathrm{a}$ retained their normal physiological functions.

\section{MATERIALS AND METHODS}

\section{Materials}

K-252a was a kind gift from Kyowa Hakko, Co., Ltd. (Tokyo). Streptomysin, penicillin G, gentamisin, minimum essential medium (MEM), and fetal bovine serum (FBS) were purchased from Sigma Co., Ltd. (St. Louis, MO, USA). Dispase was purchased from Godosyusei, Co., Ltd. (Tokyo). Acetylated LDL labelled with 1,1dioctadecyl-3,3,3', 3'tetramethyl-indo-carbocyanineperchlorate (DiI-Acetyl-LDL) and rhodamine phalloidin were purchased from Funakoshi Pharmaceutic. Co. (Tokyo). All the other chemicals were of special reagent 
grade.

\section{Cell culture}

Segments of bovine carotid arteries were obtained from adult animals at a local slaughterhouse. As soon as possible, the tissues were removed of fat and connective tissue and then transferred to the MEM including antibiotics. Their adventitia were trimmed and rinsed with MEM. They were cut longitudinally with scissors and placed on the dish so that the lumen surface was on top. The ECs were prepared by incubating these tissues with MEM containing $2000 \mathrm{U} / \mathrm{ml}$ dispase for $15 \mathrm{~min}$ at $37^{\circ} \mathrm{C}$, and then the ECs were collected by gently scraping with a scalpel blade (\#11). These cells were washed with the MEM containing 20\% FBS and placed in a 24-well culture plate (Corning, Corning, NY, USA). Cell cultures were maintained at $37^{\circ} \mathrm{C}$ and $5 \% \mathrm{CO}_{2}$, in a humidified environment. They were passaged by washing with phosphate-buffered saline (PBS), incubation with a trypsin-ethylenediaminetetraacetic acid (EDTA) solution and dispersion in the MEM with 20\% FBS. We used 5-10 passaged ECs in this study. Phase-contrast microscopy was used to assess the purity and monitor the structure of the primary cultures which attained confluency and showed a typical cobblestone appearance. Further confirmation of the identity of the cell was checked by positive immunofluorescence of DiI-acetyl-LDL (14).

\section{Acetylated LDL uptake}

Cells were seeded into a 12-well culture plate at a density of $1 \times 10^{4}$ cells $/ \mathrm{cm}^{2}$. The cells treated with or without K-252a were incubated with DiI-acetyl-LDL at a concentration of $10 \mu \mathrm{g} / \mathrm{ml}$ in the medium for $4 \mathrm{hr}$ at $37^{\circ} \mathrm{C}$. Cells were washed three times with PBS and examined with Nikon TMD microscopy (Tokyo). The fluorescence of the DiI-Acetyl-LDL taken up by the cells was visualized with standard rhodamine excitation and emission filters, and photographed with Kodak TMAX 400 film (Tokyo).

\section{Staining of actin flaments for ECs}

Cells were seeded on glass coverslips. The cells treated with or without K-252a were washed with PBS and fixed with acetone for $5 \mathrm{~min}$ at $-20^{\circ} \mathrm{C}$. They were dried at room temperature for $1 \mathrm{hr}$ and washed for $5 \mathrm{~min}$ with three changes of PBS. Cells were incubated with rhodamine-phalloidin, diluted $1 / 20$ with PBS, in the dark for 45 min and then washed with PBS. The coverslips were mounted on microscope slides using a $50 \%$ solution of glycerol in PBS containing 2.5\% 1,4-diazabicyclo-[2,2,2]octane. Stained cells were observed and photographed as described above.
Measurement of endothelin release from cultured ECs

Passaged ECs were seeded into 12-well culture plates at a density of $1 \times 10^{4}$ cells $/ \mathrm{cm}^{2}$, and after $24 \mathrm{hr}, \mathrm{K}-252 \mathrm{a}$ was added to the medium. After a 4-day treatment with $\mathrm{K}$ $252 \mathrm{a}$, control cells and the K-252a-induced giant cells almost reached confluency. Then, these cells were washed several times with MEM to exclude K-252a, and the medium was changed to DMEM/F12 medium supplemented with only $0.02 \%$ bovine serum albumin. At the indicated time, the conditioned media were collected, centrifuged at $12000 \mathrm{rpm}$ for $10 \mathrm{~min}$ to remove cells and debris, and the supernatant fluid was subjected to radioimmunoassay for endothelin. At the same time, cells were detached with trypsin-EDTA, and the cell number was determined.

Endothelin levels in the culture media were determined with a commercially available radioimmunoassay kit, which uses a rabbit antiserum for endothelin-1 and bigendothelin-1 (Amersham Japan, Tokyo). Briefly, $50 \mu$ of sample or standard, $50 \mu \mathrm{l}$ assay buffer, and $50 \mu \mathrm{l}$ antiserum were incubated for $24 \mathrm{hr}$ at $4 \mathrm{C}$, followed by the addition of $50 \mu l$ endothelin-1 labelled with iodine 125 and another 4-hr incubation at $4^{\circ} \mathrm{C}$. The bound ligands were separated from the free ligands by addition of Amerlex-M second antibody, followed by centrifugation; the supernatants obtained were decanted and the radioactivities of the pellets in each tube were counted. The minimal quantity of endothelin was $0.5 \mathrm{fmol} / \mathrm{tube}$. The antiserum used in this assay contained $37.2 \%$ big-endothelin- 1 .

\section{Measurement of calcium concentration in ECS}

Control and K-252a-induced giant cells were trypsinized and incubated with $3 \mu \mathrm{M}$ fura-2 acetoxymetyl ester (Dojin Chemical, Kumamoto) at $37^{\circ} \mathrm{C}$ for $20 \mathrm{~min}$ in buffer $\mathrm{A}\left(129 \mathrm{mM} \mathrm{NaCl}, 2.8 \mathrm{mM} \mathrm{KCl}, 0.8 \mathrm{mM} \mathrm{KH}_{2} \mathrm{PO}_{4}\right.$, $8.9 \mathrm{mM} \mathrm{NaHCO}_{3}, 0.8 \mathrm{mM} \mathrm{MgCl}_{2}, 5.6 \mathrm{mM}$ glucose, and $10 \mathrm{mM}$ Hepes, pH 7.4). The fura-2-loaded cells were resuspended in buffer $A\left(3 \times 10^{6}\right.$ cells $\left./ \mathrm{ml}\right)$ after being washed once with the buffer and then kept at room temperature. The fluorescence of fura-2-loaded cells was measured at $37^{\circ} \mathrm{C}$ with a model CAF-100 calcium analyzer (Japan Spectroscopic Co., Ltd., Tokyo) with excitation at 340 and $380 \mathrm{~nm}$ and emission at $500 \mathrm{~nm}$. Calcium concentrations were calculated according to the method of Cobbold and Rink (15).

\section{RESULTS}

\section{Effect of $K-252 a$ on the proliferation of cultured bovine} carotid ECs

At first the effect of $\mathrm{K}-252 \mathrm{a}$ on the proliferation of cultured bovine ECs was examined. The passaged cells were seeded into 12-well culture plates, and after $24 \mathrm{hr}, \mathrm{K}-252 \mathrm{a}$ was added to the medium. As shown in Fig. 1, addition of 


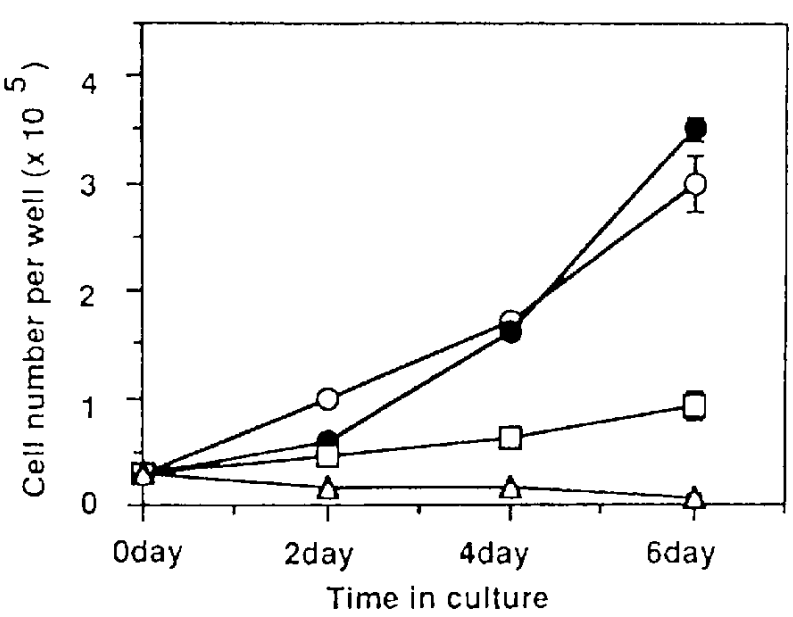

Fig. 1. Effect of K-252a on the proliferation of cultured bovine carotid cells. Random cultures were exposed to the growth medium or media containing varıous concentrations of K-252a. Control cell without K-252a (O); cells treated with $30 \mathrm{ng} / \mathrm{ml}(\mathrm{O}), 100 \mathrm{ng} / \mathrm{ml}$ $(\llcorner)$, and $300 \mathrm{ng} / \mathrm{ml}(\triangle) \mathrm{K}-252 \mathrm{a}$. At the same time indicated, cells were trypsinized and counted with a hemocytometer. Results shown are the means \pm S.E. of triplicate wells.

K-252a inhibited the proliferation of cultured bovine ECs in a dose-dependent manner, and at four days after the addition of $30 \mathrm{ng} / \mathrm{ml}$ and $100 \mathrm{ng} / \mathrm{ml} \mathrm{K-252a}$, the cell numbers were $90 \%$ and $10 \%$ of that without $\mathrm{K}-252 \mathrm{a}$, respectively. K-252a at the concentration of $300 \mathrm{ng} / \mathrm{ml}$ completely inhibited the proliferation. Once the giant cell was induced by K-252a, it could not divide nor proliferate when $\mathrm{K}-252 \mathrm{a}$ was excluded from the medium, and it was maintained for a long time in the medium without K-252a in the presence or absence of FBS (data not shown).

\section{Effect of $K-252 a$ on the morphology of cultured ECS}

At 3 or 4 days after the treatment with $500 \mathrm{ng} / \mathrm{ml} \mathrm{K}$ $252 \mathrm{a}$, more than $90 \%$ of the cultured ECs seeded at $1 \times$ $10^{4}$ cells $/ \mathrm{cm}^{2}$ became significantly larger in cell size than the control cells. The diameters of the giant cells were distributed in the range of 150 to $200 \mu \mathrm{m}$ (Fig. 2), whereas those of the control cells were about $10 \mu \mathrm{m}$. Under this condition, the giant ECs reached confluency and showed a "cobblestone" structure like the control cells (Fig. 2). Even when the ECs were seeded sparsely (less than $2 \times 10^{3}$ cells $/ \mathrm{cm}^{2}$ ) so that they were well separated from each other, a high concentration of K-252a could still induce them to become giant cells (data not shown); therefore, giant cells were not produced by fusion of the cells. Sometimes the nuclei also looked larger, two or three times the normal size. On the other hand, 3 to 4 multi-nuclei were often observed in larger giant cells. This effect of K-252a is reproducible, making it easy to obtain ECs at any time by employing this condition. The effective concentration
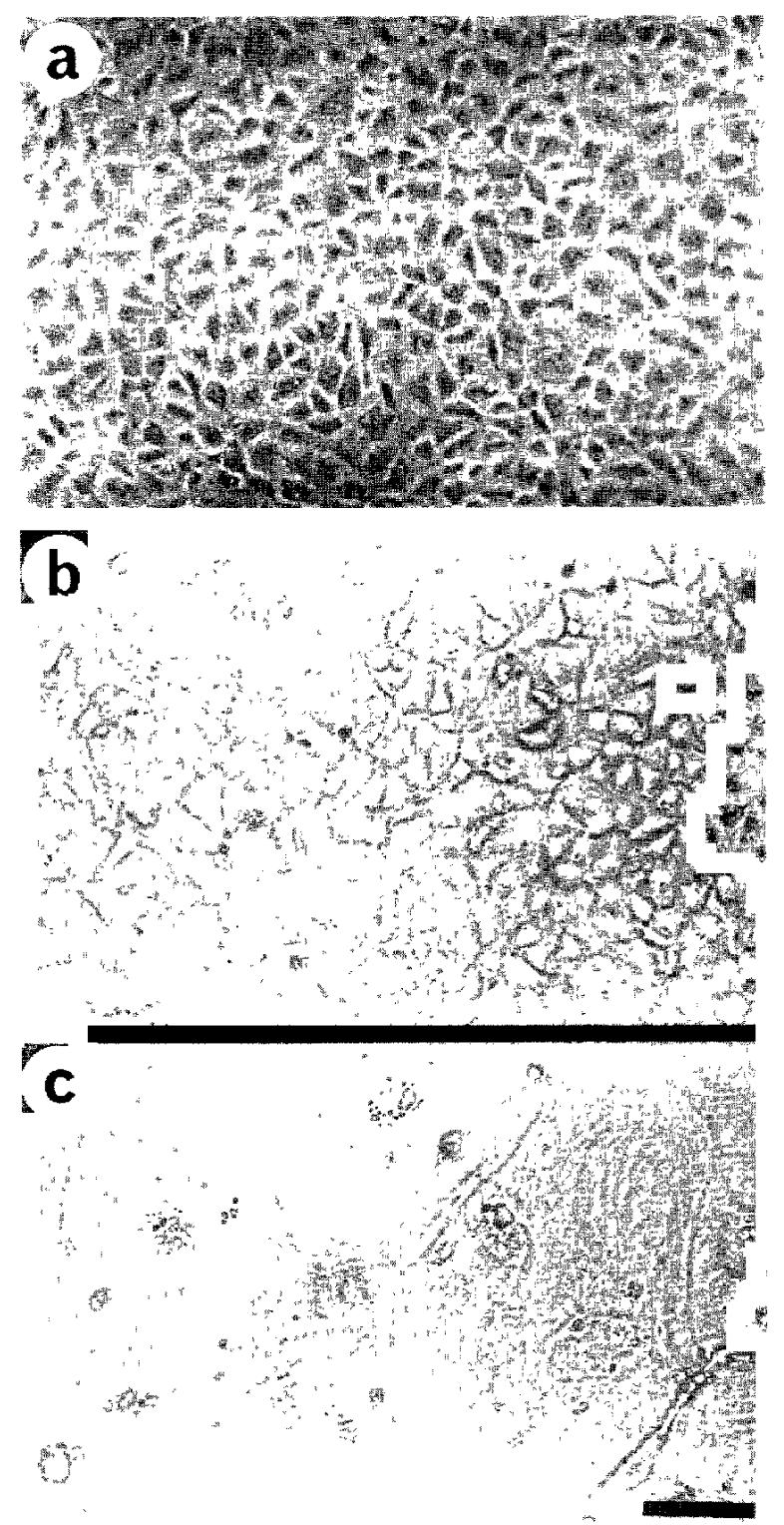

Fig. 2. Photomicrograph of the structure of the cultured ECs treated with K-252a. Cells were seeded into culture dishes at a density of $1 \times 10^{4}$ cells $/ \mathrm{cm}^{2}$ and cultured for $24 \mathrm{hr}$. The cultures were then exposed to the media without (a) or with $100 \mathrm{ng} / \mathrm{ml}$ (b) and 500 $\mathrm{ng} / \mathrm{ml}$ (c) K-252a. After 6 days, they were fixed with $1 \%$ osmium tetroxide to observe clearly the cell border and photographed. Scale bar $=100 \mu \mathrm{m}$.

range of $\mathrm{K}-252 \mathrm{a}$ for inducing giant $\mathrm{ECs}$ was $0.3-1$ $\mu \mathrm{g} / \mathrm{ml}$, which was also the range effective for producing tetraploid cells (13). When the cells were exposed to 500 $\mathrm{ng} / \mathrm{ml} \mathrm{K}-252 \mathrm{a}$ for a longer time, small vacuoles appeared around the nuclei, and more than $1 \mu \mathrm{g} / \mathrm{ml} \mathrm{K}-252 \mathrm{a}$ often damaged the cells.

Since K-252a is a multipotent inhibitor of protein kinase, the effect of the following protein kinase inhibitors at appropriate concentrations to induce inhibition of 


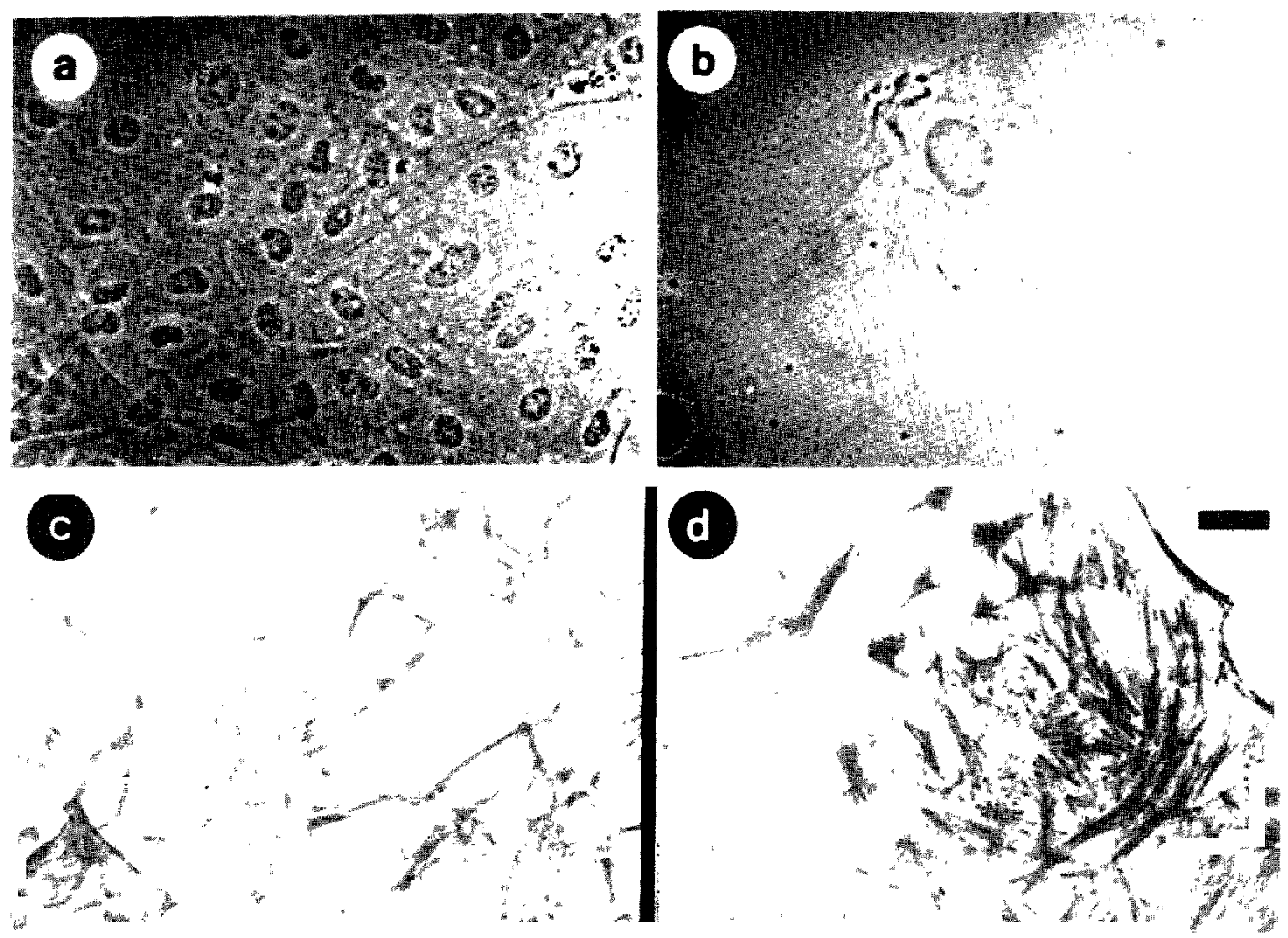

Fig. 3. F-actin staining of cultured bovine carotid ECs. Cultured ECs treated with or without K-252a as described in Fig. 2

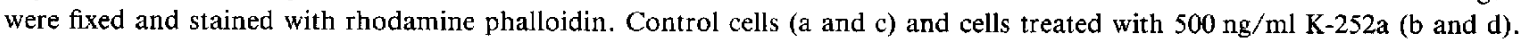
Phase contrast microscopy ( $a$ and $b$ ), fluorescent microscopy ( $c$ and d). Scale bar $=25 \mu \mathrm{m}$.

the respective kinase, especially to produce structural change, was tested: 1) Staurosporine, which more potently inhibits C-kinase than K-252a (16); 2) KT5720, which is a derivative of $\mathrm{K}-252 \mathrm{a}$ and a specific inhibitor of A-kinase in vitro (6); 3) Wortmannin, a specific inhibitor of myosin light chain kinase in vitro (17). Staurosporine at 1-100 $\mu \mathrm{g} / \mathrm{ml}$ induced morphological change, but did not enlarge the cells. KT5720 at $10-1000 \mathrm{ng} / \mathrm{ml}$ did not induce large cells. Wortmannin at $10-1000 \mathrm{ng} / \mathrm{ml}$ did not induce giant cells, but high concentration $(0.3-1 \mu \mathrm{g} / \mathrm{ml})$ induced morphological changes; the cells were rounded-up and began to detach from the substrate (data not shown).

\section{F-actin flaments in the giant ECs}

Distribution of stress fibers was investigated in the normal and K-252a-induced giant cells with the fluorescent staining by rhodamine phalloidin. Control cultures showed characteristic polygonal cells bordered by dense peripheral bands of actin, in which randomly oriented cytoplasmic stress fibers were observed (Fig. 3, a and c). Giant cells induced by K-252a had long stress fibers that appeared as intensely stained cables running in parallel to each other throughout the cytoplasm (Fig. 3, b and d). In some cells with vacuoles in the cytoplasm, stress fibers were more densely developed around the vacuoles than in the adjacent areas (data not shown). The length of the longest stress fiber in this experiment reached about $100 \mu \mathrm{m}$. Thus, stress fibers seemed to develop as the cell size increased during the treatment with K-252a. It would be interesting to know whether these longer stress fibers reflect the elongation of the actin filament itself.

\section{Physiological functions in giant EC}

It is an interesting point whether or not such abnormal giant ECs keep the same physiological functions as the control ECs. As ECs are well known to have receptors for acetyl-LDL and take it up (14), we first examimed the uptake of acetyl-LDL by the giant ECs. The abnormal giant ECs contained fluorescent deposits (punctate fluorescence) throughout the cytoplasm as well as the control cells (Fig. 4). Although the intensity of fluorescence varied from cell to cell, the fluorescent deposits were observed in all of the cells.

One of the functions characteristic to normal ECs is 


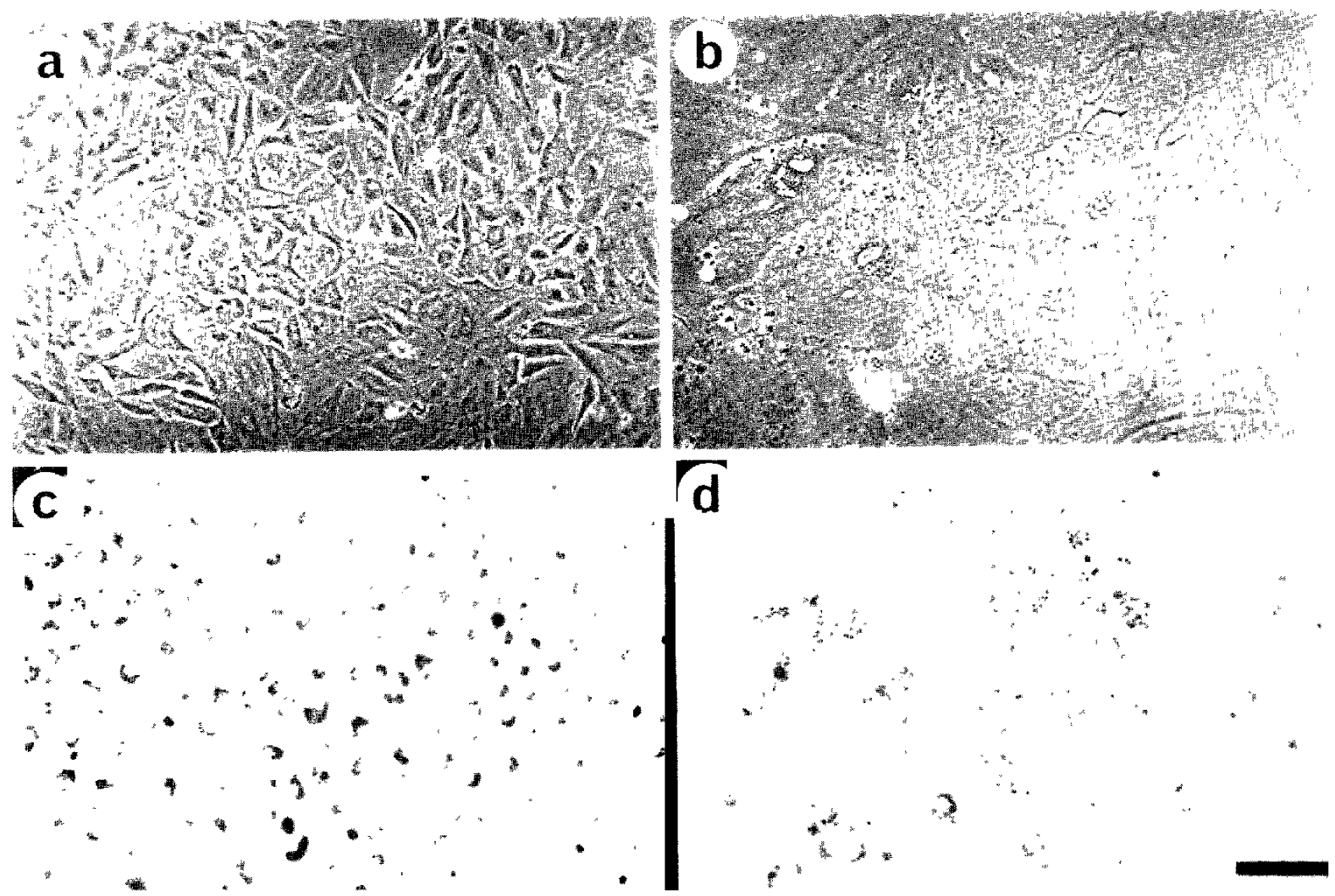

Fig. 4. DiI-Acetyl-LDL taken up by cultured bovine carotid ECs. Cultured ECs treated without or with K-252a as described in Fig. 2 were incubated with $10 \mu \mathrm{g} / \mathrm{ml}$ DiI-Acetyl-LDL for $4 \mathrm{hr}$. Control cells (a and c), cells treated with $500 \mathrm{ng} / \mathrm{ml} \mathrm{K-252 \textrm {a }}$ (b and d). Phase contrast microscopy (a and b), fluorescence microscopy (c and d). Scale bar $=100 \mu \mathrm{m}$.

production and secretion of the physiologically active substances such as endothelium derived relaxing factor and smooth muscle-contracting factor to regulate the vascular tone (18-20). Endothelin, a strong contracting factor, is spontaneously released by cultured ECs (20). This spontaneous release from giant cells to the medium was examined using antibody againist endothelin. To quantity endothelin in the medium, the medium was changed from that including both K-252a and FBS to medium without them because serum inhibited the endothelin measurement and the cells were damaged by K-252a in the absence of FBS. The giant cell retained the function of endothelin release, as shown in Fig. 5: Released endothelin was gradually accumulated in the incubation medium both in the control and giant cell cultures. In giant ECs, the release of endothelin was very markedly enhanced. Within $48 \mathrm{hr}$, control and giant cells secreted 96 and $2600 \mathrm{fmol}$ endothelin $/ 10^{4}$ cells, respectively (Fig. 5). Therefore, the amount of endothelin released from giant cells was about 30 times that released from the same number of control cells. In one series of experiments, the amount of endothelin released from the ECs treated without or with $500 \mathrm{ng} / \mathrm{ml} \mathrm{K}$ $252 \mathrm{a}$ were 54 and $2000 \mathrm{fmol} / 10^{3}$ cells $/ 96 \mathrm{hr}$, respectively.
Next, the change of $\left[\mathrm{Ca}^{2}\right]$, by stimulation with $100 \mathrm{nM}$ bradykinin was examined in both control ECs and K252a-induced giant ECs loaded with fura-2. In the presence of external $\mathrm{Ca}^{2+}$ (Fig. 6, a and c), bradykinin induced a rapid increase of $\left[\mathrm{Ca}^{2+}\right]_{1}$ followed by its gradual decrease and then the decrease in $\left[\mathrm{Ca}^{2}\right]_{1}$ leveled off to a new plateau phase. The maximal value of $\left[\mathrm{Ca}^{2+}\right]_{t}$ in the giant cells during the stimulation (c) was almost the same as that of the control (a). Since the basal $\left[\mathrm{Ca}^{2+}\right]_{1}$ level of the giant cells was higher than that of the control cells, the net increase in $\left[\mathrm{Ca}^{2+}\right]$, was bigger in the control cells than in the giant cells. However, the pattern of the response was essentially the same between the control and giant cells.

In the absence of $\mathrm{Ca}^{2+}$ with EGTA (b and d), bradykinin also increased $\left[\mathrm{Ca}^{2+}\right]_{1}$ transiently, and the $\left[\mathrm{Ca}^{2+}\right]_{1}$ arrived at the basal level within $2 \mathrm{~min}$. Both the control and giant cells showed almost the same response pattern, although the basal $\left[\mathrm{Ca}^{2+}\right]_{1}$ level of the giant cells was higher than that of the control in the presence and absence of external $\mathrm{Ca}^{2+} \cdot \mathrm{Ca}^{2+}$ may be slightly leaked from the giant cells. 


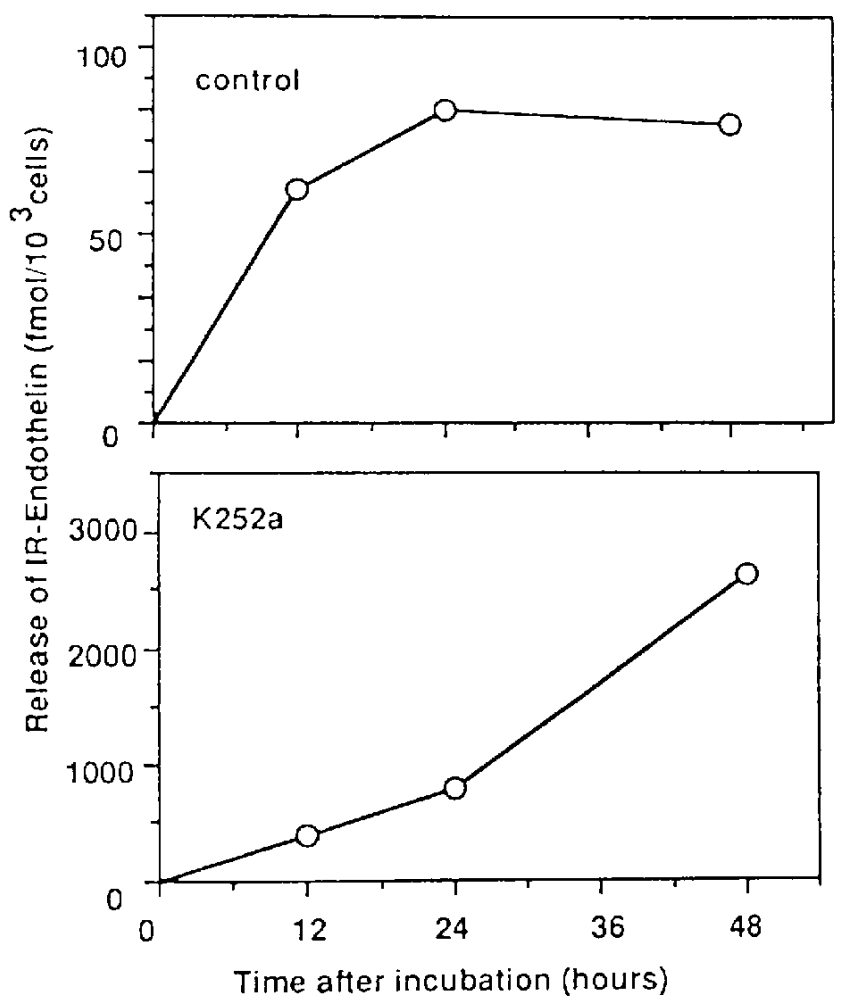

Fig. 5. Immunoreactive endothelin released from cultured bovine ECs. Control or K-252a-induced giant cells were incubated with serum-free media and at the indicated times, the quantities of endothelin were determined as described in Materials and Methods. At the same time, the cell number was counted. Results are expressed as the mean value of quantity of endothelin / mean value of cell number.

\section{DISCUSSION}

Recently Usui et al. (13) reported that K-252a induced successive DNA replication cycles uncoupled from mitosis in various cultured cell lines and that a longer inhibition with $\mathrm{K}-252 \mathrm{a}$ produced highly polyploid cells with a single giant nucleus. On the other hand, K-252a inhibited the proliferation of cultured bovine carotid smooth muscle cells (12) in the vascular system, but these cells did not show higher DNA content and induction of large cells in the presence of relatively high concentrations of K-252a (K. Ohmi, unpublished result). In the present study, K252a was found to induce abnormally large cells in primary cultured ECs. Little is known about the detailed mechanism of the growth of endothelial cells, because the modes of proliferation of endothelial cells from various sources (e.g., species and vascular organs) show a number of differences, among which are: differences in growth factors involved, growth rate, life span, and adhesive strength to substrate. Further investigation will be necessary to determine if K-252a is effective on endothelial cells other than those from bovine carotid artery which we used in this study.

The mechanism of the induction of giant ECs by K$252 \mathrm{a}$ is thought to involve some of the following actions: 1) successive DNA replication cycles without mitosis, which may result in a large nucleus with a higher DNA contents as previously reported (13), 2) cell cycle proceeds, but cytokinesis is blocked. The inhibition of cytoki-
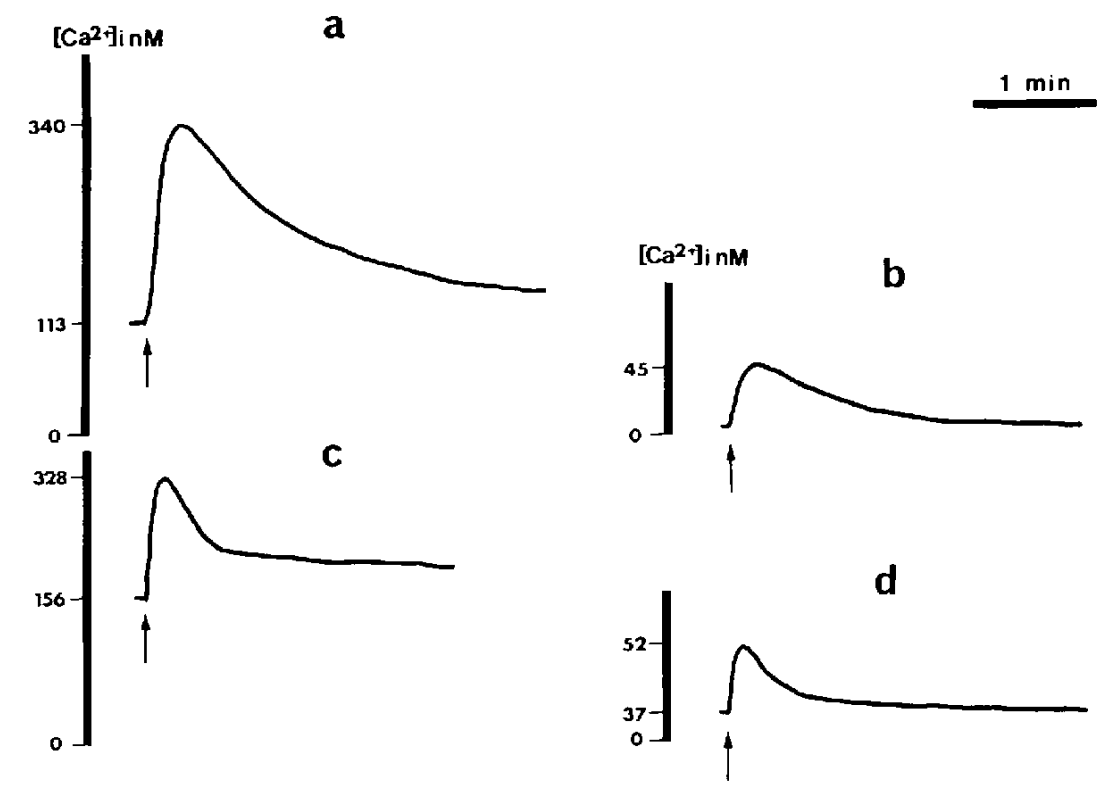

Fig. 6. Increase of $\left[\mathrm{Ca}^{2+}\right]_{\mathrm{i}}$ in cultured bovine ECs by bradykinin. Cultured control or K-252a-treated giant ECs were trypsinized and incubated with fura- 2 acetoxymethyl ester in Tyrode buffer. Then, the change of $\left[\mathrm{Ca}^{2+}\right]_{\mathrm{i}}$ by the addition of $0.1 \mu \mathrm{M}$ bradykinin in the presence of external calcium ( $a$ and c) or absence of external calcium (b and d) was measured as described in Materials and Methods. Control cell (a and b), K252-a-induced giant cell (c and d). 
nesis may be an important mechanism in the induction of large cells by K-252a. Perhaps both phenomena may simultaneously occur in the K-252a-induced giant cells.

Since K-252a is a multipotent inhibitor of protein kinase, we also tested the effect of other protein kinase inhibitors, staurosporine, KT5720 and wortmannin, but none of these inhibitors induced the formation of large cells. Staurosporine is a more potent inhibitor of Ckinase than K-252a (16). KT5720 is more specific for Akinase (6), and wortmannin was more specific for myosin light chain kinase than $\mathrm{K}-252 \mathrm{a}$ in vitro (17). Therefore, it is indicated that the target molecule(s) of K-252a is: 1) a kinase other than these three kinases; 2 ) the combined inhibition of these kinases or; 3 ) another factor, which is not a protein kinase. There have been many reports that kinases other than the above-mentioned ones are related to cell growth and the cell cycle: cdc2 kinase, tyrosine kinase, histone kinase, and so on; and furthermore, in an occasional case, one kinase may be regulated by other kinases. Hence it is also considered that K-252a may affect these kinases indirectly. In the course of investigating the effect of K-252a on the growth of vascular cells in this study, we found accidentally in endothelial cells that K-252a made all the cells markedly larger. However, many other kinds of protein kinase inhibitors are known and new ones being reported, so that there may be compounds that have the same effect as K-252a. Further experiments using these compounds will be needed to determine the target molecule(s) of K-252a for induction of such a cellular change as observed in this study.

Despite their abnormal size, the K-252a-induced giant cells maintained at least three functions characteristic to normal ECs: 1) ability to take up Dil-Acetyl-LDL (Fig. 4), 2) ability to produce and secrete endothelin (Fig. 5) and 3) ability to respond via an increase of $\left[\mathrm{Ca}^{2+}\right]_{\mathrm{i}}$ to the stimulation by bradykinin (Fig. 6). For such types of experiments as electrophysiological measurements or microinjection, the large size of the $\mathrm{K}-252 \mathrm{a}$-induced giant cells will be advantageous, and we can expect to obtain useful information more easily and more efficiently from these giant cells.

Although the giant ECs induced by the treatment with $500 \mathrm{ng} / \mathrm{ml} \mathrm{K}-252 \mathrm{a}$ released much more endothelin than the control ECs (Fig. 5), no significant increase in endothelin release was observed in the ECs treated with 100 $\mathrm{ng} / \mathrm{ml} \mathrm{K-252a}$. Under the latter condition, the size of the cells remained unchanged. This result suggests that there is a relation between endothelin release and cell size. Probably, the apparent increase of endothelin release from the giant cells was due to the increase of cell volume or cell surface area. It is not clear whether the amount of released endothelin per volume was equivalent or not between the control and giant ECs.
It is well known that activation of some receptors on the ECs' surface by vasoactive agents is coupled to an elevation of cytosolic calcium, which is caused by calcium release from the intracellular stores and by calcium entry via ion channels in the plasma membrane (21). Bradykinin has been shown to elicit phosphoinositide hydrolysis and the increase of intracellular calcium as well as the release of ECs-derived relaxing factor (22), platelet activating factor and prostacyclin (23).

Figure 6 shows a similar bradykinin-induced increase of the $\left[\mathrm{Ca}^{2+}\right]_{i}$ observed both in the control and in the giant ECs even in the absence of extracellular calcium, indicating that calcium was released from the intracellular calcium store. The result suggests that the giant EC maintains the bradykinin receptor, the receptor-coupled $\mathrm{G}$ protein, phospholipase $\mathrm{C}$ and $\mathrm{IP}_{3}$-sensitive intracellular calcium store. Moreover, since the sustained phase of $\left[\mathrm{Ca}^{2+}\right]_{1}$ observed only in the presence of extracellular calcium ions is presumably due to the entry of calcium ions through $\mathrm{Ca}$-channels, the existence of the sustained phase of $\left[\mathrm{Ca}^{2-}\right]_{i}$ in the control and giant ECs suggests the maintenance of the coupling between the bradykinin-receptor and calcium channels in the giant cell.

The K-252a-induced giant cell can be easily obtained and its large size compared with the usual cell will make it applicable for various types of experiments, making it a useful tool to search for the physiological mechanism of ECs, because the giant cells have retained several normal functions, as evidenced from the present study.

\section{Acknowledgments}

We thank Professor S. Murota, Tokyo Medical Dental University for teaching us how to prepare endothelial cells, and we thank to Drs. S. Nakanishi and Y. Matsuda, Kyowa Hakko, Co., Ltd. for preparing K-252a. This work was supported by a Grant-in-Aid for Scientific Research from the Ministry of Education, Science and Culture of Japan, Fellowships from the Japan Society for the Promotion of Science for Japanese Junior Scientists and the Fugaku Trust for Medical Research.

\section{REFERENCES}

1 Franke, R.P., Grafe, M., Schnitter, H., Seiffge, D., Mittermayer, C. and Drenckhahn, D.: Induction of human vascular endothelial stress fibres by fluid shear stress. Nature 307, 648-649 (1984)

2 Shirinsky, V.P., Antonov, A.S., Birukov, K.G., Sobolevsky, A.V., Romanov, Y.A., Kabaeva, N.V., Antonva, G.N. and Smirnov, V.N.: Mechano-chemical control of human endothelium orientation and size. J. Biol. Chem. 199, 331-339 (1989)

3 Antonov, A.S., Lukashev, M.E., Romanov, Y.A., Tkachuk, V.A., Repin, V.S. and Smirnov, V.N.: Morphological alterations in endothelial cells from human aorta and umbilical vein induced by forskolin and phorbol-12-myristate 13-acetate; a synergic action of adenylate and protein kinase $\mathrm{C}$ activators. Proc. Natl. Acad. Sci. USA. 83, 9704-9708 (1986)

4 Sandra, A.R., Bar, S., Dolash, S., Marshall, S., Kaduce, T.L. 
and Spactor, A.A.: Morphological alterations in cultured endothelial cells induced by arachidonic acid. Exp. Cell Res. 158, 484-492 (1985)

5 Takehara, K., LeRoy, E.C. and Grotendorst, G.R.: TGF inhibition of endothelial cell proliferation: alteration of EGF binding and EGF-induced growth-regulatory (competence) gene expression. Cell 49, 415-422 (1987)

6 Kase, H., Iwahashi, K., Nakanishi, S., Matuda, Y., Yamada, K., Takahashi, M., Murakata, C., Sato, A. and Kaneto, M.: K252 compounds, novel and potent inhibitors of protein kinase $\mathrm{C}$ and cyclic nucleotide-dependent protein kinases. Biochem. Biophys. Res. Commun. 142, 436-440 (1987)

7 Nakanishi, S., Yamada, K., Kase, H., Nakamura, S. and Nonomura, Y.: K252a, a novel microbial product, inhibits smooth muscle myosin light chain kinase. J. Biol. Chem. 263, $6215-6219$ (1988)

8 Eliott, L.H., Wilkinson, S.E., Sedgwick, A.D., Hill, C.H., Lawton, G., Davis, P.D. and Nixon, T.S.: K252a is a potent and selective inhibitor or phosphorylase kinase. Biochem. Biophys. Res. Commun. 171, 148-154 (1990)

9 Matsuda, Y., Nakanishi, S., Nagasawa, K., Iwahashi, K. and Kase, H.: The effect of K252a, a potent microbial inhibition of protein kinase, on activated cyclic nucleotide phosphodiesterase. Biochem. J. 256, 75-80 (1988)

10 Hashimoto, Y., Nakayama, T., Teramoto, T., Kato, H., Watanabe, T., Kinoshita, M., Tsukamoto, K., Tokunaga, K., Kurokawa, K., Nakanishi, S., Matsuda, Y. and Nonomura, Y.: Potent and preferential inhibition of $\mathrm{Ca}^{2+} /$ calmodulin-dependent protein kinase II by K252a and its derivative, KT5926. Biochem. Biophys. Res. Commun. 181, $423-429$ (1991)

11 Yamada, K., Tanaka, H., Kubo, K. and Kase, H.: Inhibition by K252a, a microbial product, of contraction of isolated rabbit arteries. Japan. J. Pharmacol. 43, Supp. 284P (1987)

12 Ohmi, K., Yamashita, S. and Nonomura, Y.: Effect of K252a, a protein kinase inhibitor, on the proliferation of vascular smooth muscle cells. Biochem. Biophys. Res. Commun. 173, 976-981 (1990)

13 Usui, T., Yoshida, M., Abe, K., Osada, H., Isono, K. and Beppu, T.: Uncoupled cell cycle without mitosis induced by a protein kinase inhibitor, K252a. J. Cell Biol. 115, 1275-1282 (1991)

14 Voyta, J.C., Via, D.P., Butterfield, C.E. and Zetter, B.R.: Identification and isolation of endothelial cells based on their increased uptake of acetylated-low density lipoprotein. J. Cell Biol. 99, 2034-2040 (1984)

15 Cobbold, P.H. and Rink, T.J.: Fluorescence and bioluminescence measurement of cytoplasmic free calcium. Biochem. J. 248, $313-328$ (1987)

16 Tamaoki, T., Nomoto, H., Takahashi, I., Kato, Y., Morimoto, M. and Tomita, F.: Staurosporine, a potent inhibitor of phospholipid $/ \mathrm{Ca}^{++}$dependent protein kinase. Biochem. Biophys. Res. Commun. 135, 397-402 (1986)

17 Nakanishi, S., Matsuda, Y., Kase, H., Hashimoto, Y. and Nonomura, Y.: Wortmannin, a microbial product inhibitor of myosin light chain kinase. J. Biol. Chem. 267, 2157-2163 (1992)

18 Furchgott, R.F.: The role of endothelium in the response of vascular smooth muscle to drugs. Annu. Rev. Pharmacol. Toxicol. 24, 175- 197 (1984)

19 Palmer, R.M., Ferrige, A.G. and Moncada, S.: Nitric oxide release accounts for the biological activity of endothelium-derived relaxing factor. Nature 327, 524-526 (1987)

20 Yanagisawa, M., Kurihara, H., Kimura, S., Tomobe, Y., Kobayashi, M., Mitui, Y., Yazaki, Y., Goto, K. and Masaki, T.: A novel potent vasoconstrictor peptide produced by yascular endothelial cells. Nature 332, 411-415 (1988)

21 Adames, D., Barakeh, J.J., Laskey, R. and Vanbreemen, C.: Ion channel and regulation of intracelluler calcium in vascular endothelial cells. FASEB J. 3, $2389-2400$ (1989)

22 Cocks, T.M., Angus, J.A., Campbell, J.H. and Campbell, G.R.: Release and properities of endothelium-derived relaxing factor (EDRF) from endothelial cells in culture. J. Cell. Physiol. 123, 310-320 (1985)

23 McIntyre, T.M., Zimmerman, G.A., Sato, K. and Prescott, S.M.: Cultured endothelial cells synthesize both platelet activating factor and prostacyclin in response to histamine, bradykinin and adenosine triphosphate. J. Clin. Invest. 76, 271-280 (1985) 